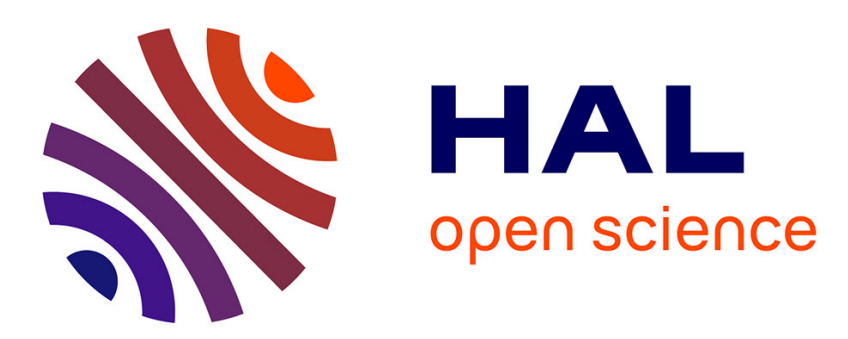

\title{
European eel distribution and body condition in a river floodplain: effect of longitudinal and lateral connectivity
}

Emilien Lasne, A. Acou, A. Vila-Gispert, P. Laffaille

\section{To cite this version:}

Emilien Lasne, A. Acou, A. Vila-Gispert, P. Laffaille. European eel distribution and body condition in a river floodplain: effect of longitudinal and lateral connectivity. Ecology of Freshwater Fish, 2008, 17 (4), pp.567 - 576. 10.1111/j.1600-0633.2008.00307.x . hal-00440331

\section{HAL Id: hal-00440331 \\ https://hal.science/hal-00440331}

Submitted on 30 May 2020

HAL is a multi-disciplinary open access archive for the deposit and dissemination of scientific research documents, whether they are published or not. The documents may come from teaching and research institutions in France or abroad, or from public or private research centers.
L'archive ouverte pluridisciplinaire HAL, est destinée au dépôt et à la diffusion de documents scientifiques de niveau recherche, publiés ou non, émanant des établissements d'enseignement et de recherche français ou étrangers, des laboratoires publics ou privés.

\section{다(1)(2)}

Distributed under a Creative Commons Attribution - ShareAlikel 4.0 International 


\section{European eel distribution and body condition in a river floodplain: effect of longitudinal and lateral connectivity}

Lasne E, Acou A, Vila-Gispert A, Laffaille P. European eel distribution and body condition in a river floodplain: effect of longitudinal and lateral connectivity.

Ecology of Freshwater Fish 2008: 17: 567-576. (C) 2008 The Authors. Journal compilation (C) 2008 Blackwell Munksgaard

Abstract - We studied eel population characteristics (size classes, densities and body condition) in the lower Loire River floodplain (France) to evaluate the effects of longitudinal and lateral gradients. A total of 36 sites were electrofished in June 2005. The sites were grouped first into three river segments according to the distance inland corresponding to a longitudinal gradient and secondly into three lateral connectivity categories. Results indicate that small eels, especially those $\leq 300 \mathrm{~mm}$, were very abundant downstream but density rapidly decreased upstream. In addition, eels $\leq 150 \mathrm{~mm}$ tended to be most abundant in connected waterbodies. Conversely, the distribution of larger eels was quite uniform across both dimensions. Eel condition decreased upstream. In parallel, in downstream river segment, eels had a lower condition in disconnected waterbodies than in connected ones. Eel specialists still have only a longitudinal perception of eel habitat. Our results suggest that lateral gradients should be also taken into consideration.
E. Lasne ${ }^{1}$, A. Acou ${ }^{1}$, A. Vila-Gispert ${ }^{2}$, P. Laffaille ${ }^{1}$

${ }^{1}$ ERT 52 'Biodiversité Fonctionnelle et Gestion des Territoires', Université de Rennes 1, Rennes, Cedex, France, ${ }^{2}$ Institut d'Ecologia Aquàtica, Universitat de Girona, Girona, Catalonia, Spain

Key words: Anguilla anguilla; body condition; lateral connectivity; distribution; large river

E. Lasne, Université de Rennes 1, ERT 52 'Biodiversité Fonctionnelle et Gestion des Territoires', Bâtiment 25, 1er étage, Campus Beaulieu, 35042 Rennes, Cedex, France; e-mail: emilien.lasne@univ-rennes1.fr

Accepted for publication March 14, 2008

\section{Introduction}

The European eel Anguilla anguilla (L.) is highly threatened throughout its distribution range (Moriarty \& Dekker 1997) and management actions are needed to restore the population (Feunteun 2002; Baisez \& Laffaille 2005; Commission of the European Community 2007). However, several studies have emphasised that the quality of the stock should be also taken into account (EELREP 2005; Acou et al. in press). For instance, pollution or parasitism might severely lower individual fitness by reducing the fecundity or the probability of reaching the Sargasso Sea (Robinet \& Feunteun 2002; EELREP 2005; Acou et al. 2008). Thus, restoration studies should focus on the relationship between the environment (i.e., quantity and quality of habitats) and the eel population characteristics (i.e., eel distribution pattern and quality) during the growth phase (i.e., the yellow eel stage) (Baisez \& Laffaille 2005).
Most studies that deal with yellow European eels in large river systems show that distance from the sea (Ibbotson et al. 2002; Feunteun et al. 2003; Lasne \& Laffaille 2008) and/or the presence of barriers to upstream migrations (Feunteun et al. 1998; Briand et al. 2005; Lasne \& Laffaille 2008) are the most important determinant factors for density and size structure of the population (Feunteun et al. 2003; Acou 2006). Generally, density decreases upstream as mean size increases. In addition, eel life-history traits usually co-vary with this spatial pattern because most of the environmental factors (temperature, salinity, productivity, etc.) that influence eel growth, sex determination, size and age at maturity (Krueger \& Oliveira 1999; Acou et al. 2003; Feunteun et al. 2003; Davey \& Jellyman 2005; Melià et al. 2006) are structured along the longitudinal gradient (Amoros \& Petts 1993). Typically, males occupy the most downstream reaches, grow quickly and mature early at a smaller size, whereas females develop slowly in 
upstream reaches and mature later at a larger size. Thus, in large systems, river segments can be separated on the basis of both eel density and the dominant phenotypes.

However, the actual decrease in the eel stock together with the reduction in longitudinal connectivity in anthropised systems means that eels are now mainly located in the most downstream areas (Lasne \& Laffaille 2008). In such a situation, a focus on patterns and processes in downstream areas, especially in large river floodplains, became very relevant. Curiously, unlike most other specialists of river ecology since the development of the Flood Pulse Concept (Junk et al. 1989), eel specialists still continue to largely ignore the process occurring in the lateral dimension of river floodplains. However, very strong environmental gradients might exist there, and could influence eels patterns (Feunteun et al. 2003). First, variable hydrological connectivity along the floodplain lateral gradient leads to great habitat heterogeneity (Amoros 2001; Amoros \& Bornette 2002; Tockner et al. 1999; Lasne et al. 2007). In relatively pristine systems, it is possible to find a variety of aquatic habitats ranging from lotic (main channel and side arms) to lentic (disconnected waterbodies) that lead to contrasting environmental conditions (e.g., in terms of water velocity, aquatic vegetation cover, substrate size, temperature or conductivity). Numerous studies have shown that fish distribution across the floodplain is highly heterogeneous and related to individual species requirements, with species velocity preference being crucial (Copp 1989; Aarts et al. 2004; Lasne et al. 2007). Secondly, connectivity with the main channel is likely to lead to variable habitat accessibility. For instance, in an Amazonian floodplain, GranadoLorencio et al. (2005) showed that the connectivity level influences the distribution patterns of migratory fishes. Thus, the lateral distribution of eels across a large floodplain is likely to be heterogeneous. Moreover, thermal conditions and food availability (especially invertebrates; Amoros \& Petts 1993; Garcia \& Laville 2000; Reckendorfer et al. 2006) along the lateral gradient can lead to fish having contrasting growth rates (Ribeiro et al. 2004). With eels, some studies have suggested that variable growth rates caused by habitat heterogeneity also exist (Chisnall 1989; Domingos et al. 2006). Therefore, it is likely that contrasting eel characteristics could be observed in large floodplains.

In this study, we investigated eel distribution patterns in a $140 \mathrm{~km}$-long section of the lower Loire River floodplain. A recent study carried out in this floodplain showed that both habitat features and fish assemblages were very contrasted in relation to a connectivity gradient (Lasne et al. 2007). More particularly, isolated waterbodies had a lower species richness and hosted mainly stress-tolerant (i.e., eurytopic) species. Therefore, we first tested whether various connectivity levels influence eel distribution. More specifically, it was supposed that lower connectivity levels should reduce habitat accessibility and/or quality and consequently eel density. Secondly, we examined whether hydrological connectivity influences eel body condition (a proxy of fitness). It was expected that eels in isolated waterbodies have a lower condition, in relation to harsher conditions and/or reduced movement opportunity.

\section{Materials and methods}

\section{Study area}

The study was undertaken in the downstream reaches of the Loire River, France (Fig. 1). The position of the Loire catchment on the Atlantic coast enables it to be extensively colonised by glass eels (Baisez \& Laffaille 2005). In this system, before entering freshwater glass eels have to pass up a long estuary $\left(55 \mathrm{~km}^{2}\right.$ including $32 \mathrm{~km}^{2}$ always inundated) where they are subjected to intensive fishing pressure. In this river system, eels can find growing areas in brackish estuarine reaches and therefore, they might never penetrate into freshwater (Daverat \& Tomas 2006).

The most downstream section of the study area was subjected to tidal influence and the downstream limit was located near the limit of salt water intrusion in the main channel (this limit corresponds to extreme and therefore rare events, i.e., low flow, high tide/spring tide). This sector roughly matches with the tidal freshwater estuary (Daverat \& Tomas 2006). Conversely, the rest of the study sector was outside tidal influence. Water within the study sites was fresh (i.e., salinity close to 0 ) including the two lower ones located just downstream the limit of salt water intrusion. Migrating eels are free to move upstream as there are no barriers affecting the study area (Lasne \& Laffaille 2008). The floodplain is large, relatively little impacted and has numerous kinds of waterbodies more or less connected to the main channel (Lasne et al. 2007).

We sampled a total of 36 waterbodies (Fig. 1). In order to test the effect of the longitudinal gradient, we divided the study area into three segments (Fig. 1). Segment A included all sites located downstream of the limit of tidal influence, i.e., in the tidal freshwater part of the river. Segment B was located between the tidal limit and the confluence with the Maine River, near Angers. The upstream limit of segment $\mathrm{C}$ was located at the confluence with the Vienne River, near Saumur.

To test the effect of the position of the waterbodies along the lateral gradient, sampling sites were classified 
Fig. 1. Location of the 36 sampling sites along the Loire River. The study area is divided into three segments: A, B and C. Numbers refer to connectivity level of each site (see Fig. 2 for details).

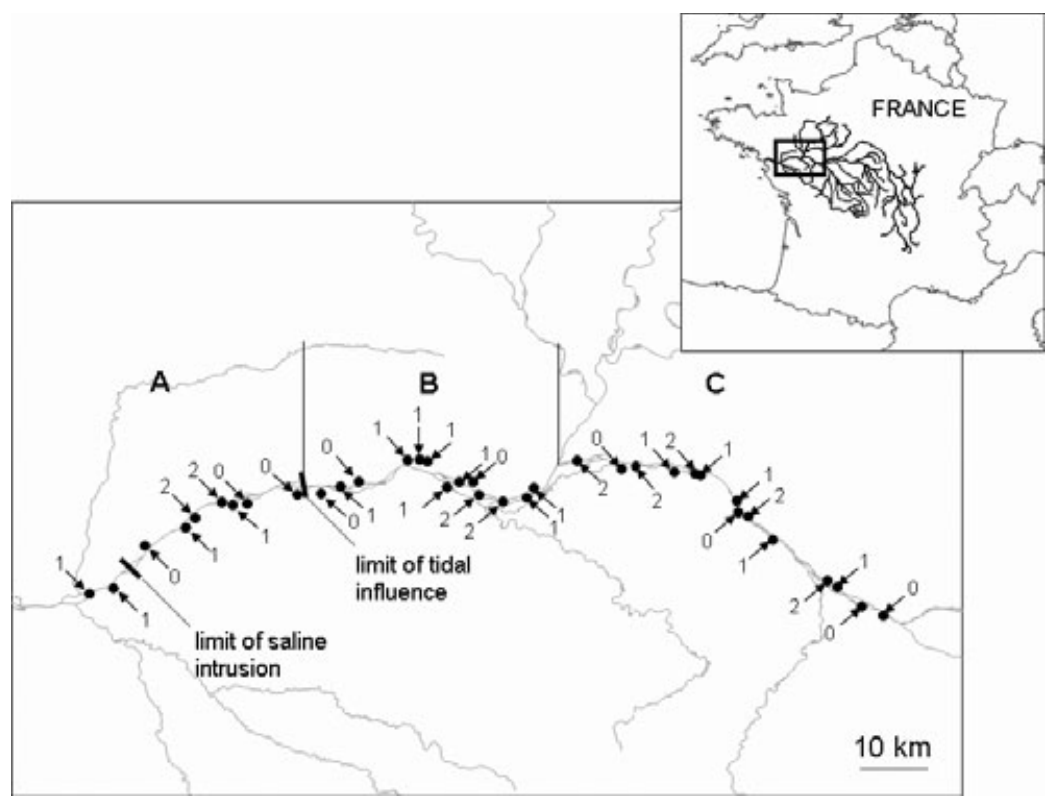

according to three levels of connectivity, which were based on (i) their type of connection to the mainstem, (ii) the frequency of connection and (iii) their accessibility during the sampling period (Figs 1 and 2; modified after Lasne et al. 2007). Waterbodies of type 0 and 1 were disconnected from the main channel at sampling period (early June 2005). However, type 0

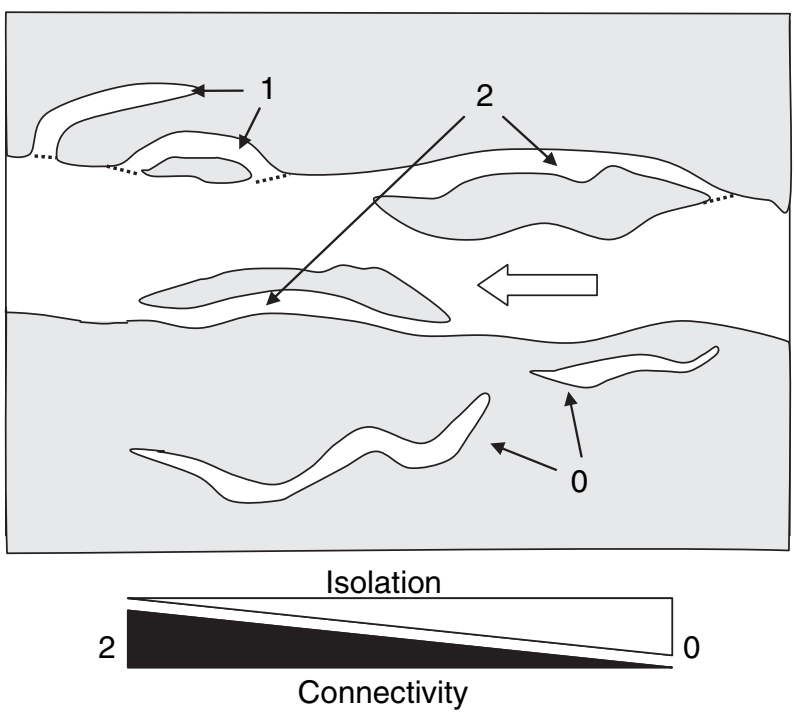

Fig. 2. Typology of the connectivity in the lateral gradient of the floodplain. Three levels of connectivity are distinguished on the basis of the type of connection during the sampling period. Sites of type 0 are only connected to the main channel at high water levels, sites of type 1 are connected at intermediate water levels but temporarily disconnected when river levels are low and sites of type 2 are connected during most of the year, including the sampling period. Dotted lines show disconnections of waterbodies during low water levels and the large arrow shows the direction of the flow. corresponds to sites only connected during high winter flows and water levels, whereas type 1 corresponds to sites highly accessible during a large period of the year. This type corresponds to secondary channels or backwaters that have temporary disconnections at low water levels. Finally, type 2 corresponds to sites highly accessible, i.e., eels are free to move in and out of the waterbody.

Such a connectivity gradient across the floodplain might regulate not only the movement opportunity of fish, especially migratory species such as eel, but also environmental conditions. Lasne et al. (2007) showed for instance that aquatic vegetation cover or substrate size varied according to connectivity, with connected sites having little vegetation cover and having sandy substrate, whereas isolated sites tend to have high levels of vegetation and silty substrates. Incidentally, the sandy-bottom connected sites would be expected to be more suited to cryptic behaviour in small, compared with large, eels. However, shelters for large eels (i.e., boulders, riprap banks, roots or woody debris) might also be present in waterbodies irrespective of the connectivity level.

\section{Eel sampling}

Sampling was conducted in early June 2005. At this time of the year, water levels are normally low, and heterogeneity across the floodplain is high (Ward \& Tockner 2001; Lasne et al. 2007; Thomaz et al. 2007). Eels were collected by wading with electroshocker (FEG 8000, EFKO, Leutkirch, Germany; DC, 300-600 V, 6-8 A). Electrofishing by wading meant that deeper waters $(>1.20 \mathrm{~m})$ were not sampled, but this method is in any case poorly efficient in 


\section{Lasne et al.}

such habitats. We used a $30 \mathrm{~cm}$ diameter anode on $2 \mathrm{~m}$ long pole following the point abundance samples (PAS) methodology (Nelva et al. 1979). At each site, a total of 25-35 PAS was made in the various habitats present to obtain a reliable estimate of the relative abundance and structure of the eel stocks (see Laffaille et al. 2005b). Fish were anaesthetised in the field with clove oil and total body length was measured to the nearest $\mathrm{mm}$. Individuals $\geq 200 \mathrm{~mm}$ were also weighed $(g \pm 1)$ for body condition analysis. Smaller eels were not weighed because of potential errors in weight measurement on the field. According to the characterisation methods of Acou et al. $(2005,2006)$, none of the eels sampled could be considered as being silver eels so they were all in the colonising or growing stage. All individuals were released after collection of biological data.

\section{Data analyses}

\section{Distribution patterns}

The distribution of eels was analysed along the longitudinal and lateral gradients by grouping sites according to river segment (A, B or C) and connectivity $(0,1$ or 2$)$. Thus, we obtained nine groups: A0, A1, A2, B0, B1, B2, C0, C1 and $\mathrm{C} 2$ (Table 1). We used the mean number of eels per PAS (i.e., catch per unit effort; eel $\mathrm{PAS}^{-1}$ ) as an index of density. We first considered all size classes together. Secondly, based on the assumption that behaviour and habitat requirements change with eel size, we examined the distribution for different size classes as did Lasne \& Laffaille (2008). However, given the low abundance of eel $>650 \mathrm{~mm}$, we pooled all individuals $>450 \mathrm{~mm}$ together. Finally, the data set was then split into four size classes: $\leq 150,151-300$, $301-450$ and $>450 \mathrm{~mm}$. Homogeneity of density among groups was evaluated using Kruskal-Wallis (KW) tests with $\alpha=0.05$.

\section{Body condition}

We followed the protocol of Vila-Gispert et al. (2000) to compare eel condition among groups (i.e., A0-C2). We preferred this method to the classical index of Fulton (Cone 1989) because it totally removes the effect of size on body condition (Cone

Table 1. Number of eels $\geq 200 \mathrm{~mm}$ caught per river segment and connectivity level, used for length and weight records.

\begin{tabular}{llrr}
\hline Connectivity & \multicolumn{2}{l}{ River segments } & \\
\hline & A & B & C \\
0 & 84 & 40 & 3 \\
1 & 70 & 170 & 30 \\
2 & 51 & 17 & 45 \\
\hline
\end{tabular}

1989; Packard \& Boardman 1999). Indeed, in most fish, including eels (Melià et al. 2006), the index of Fulton increases as length increases. In a recent study, the protocol of Vila-Gispert et al. (2000) has been successfully applied to make comparisons of eel condition (Acou et al. 2008). We, therefore, applied an ANCOVA procedure with mass as the dependent variable and length as a covariate. Mass-length relationships were linearised by $\ln$-transformation. First, we tested the homogeneity of slopes among groups. If the interaction between length (i.e., covariate) and group (factor) was not significant $(P<0.05)$, secondly, a standard ANCOVA was applied to compare the $y$-intercept of the mass-length relationships among groups. Post hoc test (HSD Tukey) was used to identify groups with different intercepts. All analyses were performed using $\mathrm{R}$ software (Ihaka \& Gentleman 1996).

\section{Results}

A total of 1006 PAS was performed, and 1029 eels ranging from 53 to $849 \mathrm{~mm}$ (average $234 \pm 142 \mathrm{~mm}$ ) were caught.

\section{Size class distribution patterns}

The total density of eels (i.e., all size classes pooled) was significantly different among site groups $(\mathrm{KW}=27.388 ; P<0.001 ;$ Fig. 3$)$. Densities were higher in river segment A irrespective of the connectivity level and decreased upstream. In A, densities tended to be lower in disconnected sites compared with connected ones, and above all, densities were more variable as shown by error bars. This was not true in other compartments.

When considering size classes separately, it appeared that total density patterns were mainly influenced by small eels ( $\leq 150$ and $151-300 \mathrm{~mm}$ ) patterns which indicated a heterogeneous distribution $(\mathrm{KW}=28.138 ; \quad P<0.0001 \quad$ and $\quad \mathrm{KW}=27.628$; $P<0.001$, respectively) in the longitudinal gradient. For these two size classes, densities were highest in segment A and decreased upstream. In particular, eels $\leq 150 \mathrm{~mm}$ were almost totally absent from segments B and $\mathrm{C}$, and 151-300 $\mathrm{mm}$ eels were also almost absent from segment C. Density of eels $>300 \mathrm{~mm}$ was always low and constant over waterbody groups $(\mathrm{KW}=9.915 ; \quad P=0.271 \quad$ and $\quad \mathrm{KW}=11.742$; $P=0.163$, respectively, for $301-450 \mathrm{~mm}$ eels and for eels $>450 \mathrm{~mm}$ ). Only the density of eels $\leq 150 \mathrm{~mm}$ tended to be heterogeneous along the lateral gradient, but only in compartment A (Fig. 3). Indeed, density was always high in connected waterbodies, whereas it was on average lower and more variable in isolated ones. 


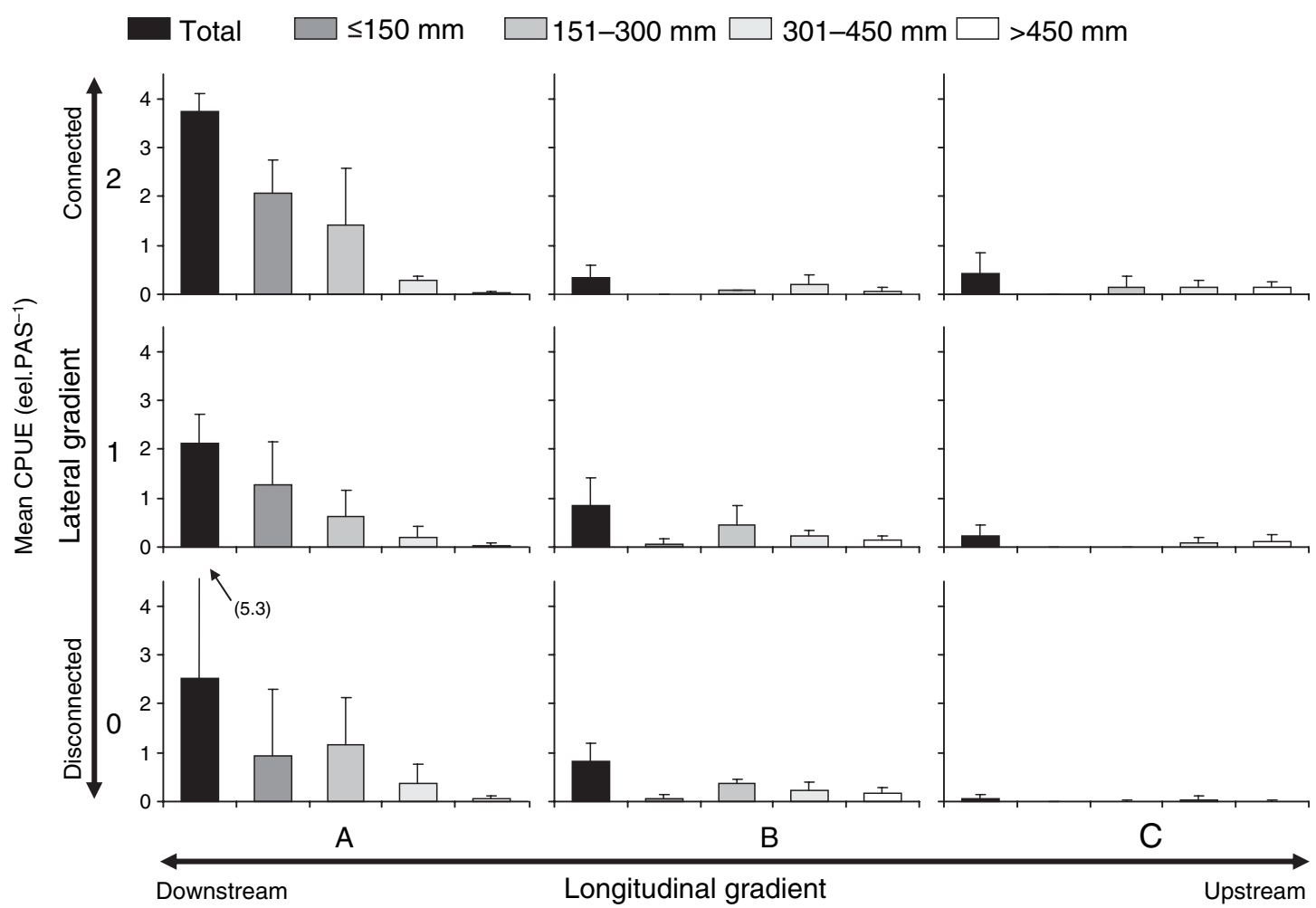

Fig. 3. Mean CPUE (mean number of eels $\mathrm{PAS}^{-1}$ ) in each group for four eel size classes. Along the longitudinal gradient, segment $\mathrm{A}$ is downstream, B intermediate and $\mathrm{C}$ upstream. Connectivity increases in the lateral gradient from 0 to 2 . See text and Figs 1 and 2 for details on longitudinal and lateral gradients.

\section{Body condition patterns}

Among the 1029 eels caught in the 36 sampling sites, only 510 eels $\geq 200 \mathrm{~mm}$ were individually weighed (Table 1) for mass-length relationship analyses. Unfortunately, not enough individuals $(<10)$ were available in group $\mathrm{C} 0$ (Table 1 ) due to very small densities in this upstream compartment, especially in disconnected waterbodies (Fig. 3). Other groups had enough data and were therefore included in the ANCOVA procedure.

In the first model (model 1; Table 2), the interaction between covariate (i.e., length) and factor (i.e., group) was not significant, indicating that the slopes of the regressions were homogeneous. The second model

Table 2. Results of the ancova procedure. The first model was built to verify the homogeneity of slopes between sites groups $(\alpha=0.05)$. Model 2 was built to test for differences in $y$-intercepts between groups $(\alpha=0.05)$.

\begin{tabular}{lrlr}
\hline Source of variation & $F$ & d.f. & $P$-value \\
\hline Model 1 (test for interaction) & & & \\
In(length) & 36530.84 & 1 & $<0.000$ \\
Group & 11.74 & 7 & $<0.000$ \\
In(length) $\times$ group & 0.83 & 7 & 0.567 \\
Model 2 (no interaction) & & & \\
$\quad$ In(length) & 36620.89 & 1 & $<0.000$ \\
Group & 11.77 & 7 & $<0.000$ \\
\hline
\end{tabular}

(model 2, without interaction; Table 2) showed that $y$-intercepts of the mass-length relationship were different between groups and pairwise significant differences were found between groups (Fig. 4). When considering sampling sites of types 1 and 2 , fish condition decreased significantly upstream. Regardless of the river segment, there were no significant differences between condition of eels in sites of connectivity type 1 and 2 . However, in segment A,

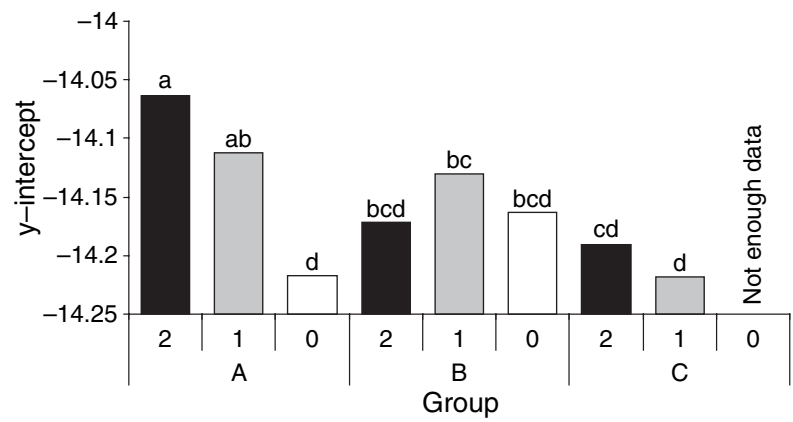

Fig. 4. Value of the $y$-intercept of the $\ln ($ mass $)=f[\ln ($ length $)]$ regression for 510 eels $\geq 200 \mathrm{~mm}$ estimated by the ANCOVA procedure (model 2, see text and Table 2). Letters above the bars show pairwise differences (HSD Tukey test, $\alpha=0.05$ ). Not enough data were available to include group $\mathrm{C} 0$ in the model. Same letters on top of the bars indicate that values are not statistically different. 
eels in the most isolated sites (type 0) had a significantly lower condition, almost equivalent to the condition of eels found in the uppermost reaches (i.e., in compartment C).

\section{Discussion}

\section{Longitudinal patterns}

Most studies that deal with European eel distribution at a catchment or river scale show a decrease in density or occurrence along the longitudinal gradient (Ibbotson et al. 2002; Feunteun et al. 2003; Briand et al. 2005). However, this pattern might not occur in very small systems where young recruits might invade the whole catchment and reach upstream reaches after their first colonisation season (Laffaille et al. 2003; Acou 2006). In addition, the mean size of eels increases upstream as density of small eels decreases (Feunteun et al. 2003). In our study, similar patterns were found despite the relatively small length of the study sector (140 km compared with the $1012 \mathrm{~km}$ of the total length of the Loire River), closeness to the estuary (segment $\mathrm{A}$ is subjected to the tidal influence) and the absence of barriers to migration.

In segment A, most eels collected were $\leq 300 \mathrm{~mm}$. According to Feunteun et al. (2003), the upper estuary roughly corresponds to the high-density area where young recruits accumulate before migrating to peripheral low density areas (i.e., compartments B and C). Under the assumption of density-dependent upstream migratory behaviour (Moriarty 1986; Feunteun et al. 2003), high densities in downstream areas should lead to a significant colonisation of upstream reaches (Ibbotson et al. 2002). Conversely, the reduction in recruitment and density downstream should reduce the migratory behaviour at both an individual and a population level (Edeline 2007). In our study, river segment $C$ was located between $\mathrm{km} 40$ and $\mathrm{km} 100$ from the tidal limit but was free of small eels (e.g., $\leq 300 \mathrm{~mm}$ ) whereas it is highly accessible for such individuals (based on a mean migration rate of $10-75 \mathrm{~km}$ a year; Aprahamian 1988; Baras et al. 1996; Briand et al. 2005). Although the colonisation of tributaries (including the large Maine River) probably contributes to the decreasing density along the main axis of the Loire and its floodplain, this result suggests that the fluvial recruitment in this catchment is low and the eel population in the downstream reaches of the Loire River is far below its potential carrying capacity.

The patterns described along the study sector are consistent with the results of Lasne \& Laffaille (2008). Using long-term presence-absence data from the entire Loire catchment, these authors showed that occurrence probabilities of eels $\leq 300 \mathrm{~mm}$, and especially of eels $\leq 150 \mathrm{~mm}$, decrease very rapidly upstream (e.g., occurrence probability of $\leq 150 \mathrm{~mm}$ eels is null upstream of the confluence with the Maine catchment). Conversely, larger eels tended to go further inland. Although presence-absence data and catch per unit effort do not exactly provide the same information and sampling protocols of the two studies were quite different, our results indicate that the longitudinal structure of the stock of juvenile yellow eels (i.e., $\leq 300 \mathrm{~mm}$ eels) in the Loire floodplain provides a good indication of the colonisation level in the entire catchment. Quantitative sampling of eels is not possible in the deeper parts of large rivers like the Loire, but it appears that electrofishing in type 2 waterbodies can reveal useful information about colonisation by small eels - recognising that larger eels might be present in deeper waters and consequently, their density is probably underestimated. In addition, whilst studies of type 1 and 0 lateral waterbodies can also be useful, it needs to be pointed out that variability can be high, depending on the distance from the main channel, temporal connection history, waterbody permanency, etc. (e.g., see Lasne et al. 2007).

The analysis of the body condition revealed that eels were relatively fatter in the lower reaches of the study area which was located in the tidal freshwater zone of the estuary, whereas segments B and C were outside tidal influence. According to Mounaix \& Fontenelle (1994), Acou et al. (2003) and Daverat \& Tomas (2006), conditions in coastal and estuarine brackish waters lead to a higher and more constant eel growth than straight riverine reaches. Indeed, estuaries are generally highly productive, and in addition, offer buffered conditions, especially in terms of temperature (Mounaix \& Fontenelle 1994; Morrison \& Secor 2003; Daverat et al. 2006; Costa et al. 2008). Although water was fresh in segment A, it is very likely that the higher body condition of individuals located in this segment is the result of the proximity of brackish waters which probably provides good environmental conditions for eel growth. Indeed, in segment $\mathrm{A}$, most eels are $\leq 300 \mathrm{~mm}$ and considered as active colonisers (Feunteun et al. 2003; Lasne \& Laffaille 2008), therefore, probably arising straight from downstream productive areas and undertaking river colonisation with a high body condition. It is also possible that 'nomadic' (according to the description of Feunteun et al. 2003) eels in downstream locations move from the riverine compartment to the estuarine one and/or vice versa (Daverat \& Tomas 2006; Daverat et al. 2006). For instance, eels in type 2 waterbodies might be able to disperse and forage in the main river channel. Conversely, upstream compartments are mainly occupied by large individuals that exhibit little migratory behaviour, eels described as 'sedentary' by Laffaille et al. (2005a). 


\section{Lateral distribution patterns}

To date, no study has clearly addressed the question of eel distribution patterns along a lateral connectivity gradient. In the Loire floodplain, the density of eels was high in all connected waterbodies of the tidal freshwater sector of the Loire (segment A). However, this was mainly due to the density of small eels which was high in connected waterbodies (type 2) and tended to decrease in isolated ones (type 1 and then 0). Except for small eels, density of all size classes was quite homogeneous among connectivity types irrespective of the river segment. Two synergic but not exclusive mechanisms might explain such contrasting patterns. As mentioned earlier, there is a double gradient across large floodplains: a gradient of accessibility (GranadoLorencio et al. 2005) and a gradient of habitat condition (Aarts et al. 2004; Tockner et al. 1999; Lasne et al. 2007) with each possibly playing an important role.

First, small eels might be less likely to colonise disconnected waterbodies because of a low accessibility. Research that deals with eel migratory patterns has shown that eel movements mainly concern small individuals and occur in late spring when water temperature increases (Moriarty 1986; Naismith \& Knights 1988; Acou 2006). In general, during this period, eels arriving from downstream reaches cannot penetrate into disconnected waterbodies (type 0) because water levels are often low and these waterbodies are already physically isolated, resulting in a lower eel density. However, as shown in Fig. 3, standard errors of density of eels $\leq 300 \mathrm{~mm}$ and especially $\leq 150 \mathrm{~mm}$ in A0 were quite high indicating a large variability. This variability was mainly due to the most downstream site of group A0 which had a high density of eels (density of $\leq 150 \mathrm{~mm}=2.5$ eels $\mathrm{PAS}^{-1}$ ). The accessibility of this site was enhanced by the existence of a little outlet which flows into the Loire in the spring and therefore allows the smallest eels to colonise the waterbody irrespective of the water level of the Loire itself. Such a special case emphasises the complexity of measuring connectivity, especially for a highly mobile species such as the European eel, and the need to consider other kinds of connection. Unfortunately, such connections (e.g., temporary brook, ditch networks) might be difficult to identify and quantify. This site aside, the mean density of $\leq 150 \mathrm{~mm}$ eels in other A0 sites was very low $\left(0.16 \pm 0.09\right.$ eels PAS $\left.^{-1}\right)$. Conversely, most large eels have a sedentary behaviour (Laffaille et al. 2005a) and are 'home range dwellers' (Feunteun et al. 2003). Such individuals are generally older and have several opportunities through their life to colonise waterbodies of types 1 and 0 during floods. Finally, their distribution is quite homogeneous across the floodplain. Thus, our results suggest that density patterns across the floodplain could result from variable temporal accessibility.

Secondly, small eels might avoid disconnected waterbodies because they present unsuitable habitat conditions. Eels are known to be largely ubiquitous and opportunistic (i.e., they are able to use a wide range of aquatic habitats; Feunteun 1994), but strong size-related habitat preferences might exist in rivers (Laffaille et al. 2003; Domingos et al. 2006) and in wetlands (Laffaille et al. 2004). Hence, it is possible that heterogeneity of small eel distribution in the lateral dimension results from habitat selection. On the contrary, density of eels $>150 \mathrm{~mm}$ was quite homogeneous between these different habitat types suggesting that the distribution of larger eels is not significantly influenced by these habitat conditions.

Our results also show that the mean body condition of eels decreases as lateral connectivity decreases in segment A whereas no clear trend appeared in segment B. Furthermore, there were too few eels collected from group $\mathrm{C} 0$ to include in data analyses. This suggests that disconnected habitats are less suitable than connected ones, either because environmental characteristics are less favourable than in more connected sites (habitat condition hypothesis), or because eels in these habitats have little opportunities to colonise it (habitat accessibility hypothesis). It is also possible that eels with low body condition stop in disconnected waterbodies because they do not have enough energetic reserves to start upstream colonisation. Such hypothesis is in accordance with Edeline et al. (2006) who found that migratory behaviour was stimulated via hormone secretion - by high energetic reserves.

\section{Conservation implications}

Today, eel distribution is being more and more restricted to downstream reaches of rivers, first because of the decreasing recruitment, and secondly because of longitudinal connectivity alteration. Thus, in the context of eel decline, downstream floodplains of large river systems are probably of great importance for the species. Our study is the first that reveals the influence of lateral hydrological connectivity across the floodplain on the European eel. Furthermore, we hypothesise that the environmental and demographic heterogeneity observed at the floodplain scale produces variable phenotypes and tactics. According to the role of energetic reserves on the determinism of phenotype (e.g., migratory vs. sedentary; see Edeline et al. 2006; Edeline 2007), the effect of connectivity on body condition shown in this study is in accordance with this hypothesis. One can also suppose that locally contrasted density patterns and condition would lead to spatially variable sex ratio, with males being mainly 
produced in high density waterbodies and females in low density ones.

Although the Loire River still has a near-natural flow regime and a large floodplain with high habitat diversity, this is far from being the case for most large European systems (Tockner \& Stanford 2002). Indeed, floodplains are often highly altered, and lateral connectivity has been reduced by channelisation or flow regulation (Tockner \& Stanford 2002). Considering the role of environmental and demographic conditions in downstream areas as determinants of various phenotypes and tactics (Edeline 2007), the consequences of floodplain habitat loss or modification for the eel population at both small (i.e., local or catchment stock) and large (i.e., whole population) scales need to be examined in detail in further research.

\section{Acknowledgements}

This study was funded by DIREN Pays-de-la-Loire, Agence de l'eau Loire-Bretagne and Conseil Régional Pays-de-la-Loire. Technical support was provided by the Tableau de Bord Anguille du bassin de la Loire, des Côtiers Vendéens et de la Sèvre Niortaise (Aurore Baisez) and Fish-Pass. Special thanks to Julien Cucherousset, Martin Lajournade, Johan Bonot and Matthieu Leray for field contribution. Thanks to Rosine Binard for helpful comments, and to Jacques Boubée for contribution in last spelling improvement. Finally, we thank two anonymous reviewers for very constructive comments on an earlier version of the manuscript.

\section{References}

Aarts, B.G.W., Van den Brink, F.W.B. \& Nienhuis, P.H. 2004. Habitat loss as the main cause of the slow recovery of fish faunas of regulated rivers in Europe: the transversal floodplain gradient. River Research and Applications 20: 323.

Acou, A. 2006. Bases biologiques d'un modèle pour estimer la biomasse féconde de l'anguille européenne en fonction des recrues fluviales et du contexte de croissance : approche comparative à l'échelle de petits bassins versants. $\mathrm{PhD}$. thesis. Rennes: University of Rennes 1.316 pp. URL http:// www.diadfish.org/francais/documents_f.htm.

Acou, A., Lefebvre, F., Contournet, P., Poizat, G., Panfili, J. \& Crivelli, A.J. 2003. Silvering of female eels (Anguilla anguilla) in two sub-populations of the Rhône Delta. Bulletin Français de la Pêche et de la Pisciculture 368: 55-68.

Acou, A., Boury, P., Laffaille, P., Crivelli, A.J. \& Feunteun, E. 2005. Towards a standardized characterization of the potentially migrating silver European eel (Anguilla anguilla). Archiv für Hydrobiologie 164: 237-255.

Acou, A., Poizat, G. \& Crivelli, A.J. 2006. Errors in ocular index measurements in European eel Anguilla anguilla. Ecology of Freshwater Fish 15: 578-582.

Acou, A., Gabriel, G., Laffaille, P. \& Feunteun, E. in press. Differential production and condition indices of premigrant eels (Anguilla anguilla) in two small Atlantic coastal catchments of France. In: Casselman, J.H. \& Cairns, D.K., eds. Proceedings of the 2003 International Eel Symposium Eels at the Edge: Science, Status, and Conservation Concerns. American Fisheries Society Symposium Publication. Bethesda, MD.

Acou, A., Robinet, T., Lance, E., Gerard, C., Mounaix, B., Brient, L., Le Rouzic, B. \& Feunteun, E. 2008. Evidence of silver eels contamination by microcystin-LR at the onset of their seaward migration: what consequences for breeding potential? Journal of Fish Biology 72: 753-762.

Amoros, C. 2001. The concept of habitat diversity between and within ecosystems applied to a river side-arm restoration. Environmental Management 28: 805-817.

Amoros, C. \& Bornette, G. 2002. Connectivity and biocomplexity in waterbodies of riverine floodplains. Freshwater Biology 47: 761-776.

Amoros, C. \& Petts, G.E. 1993. Hydrosystèmes fluviaux. Paris: Masson, $300 \mathrm{pp}$.

Aprahamian, M.W. 1988. Age structure of eel, Anguilla anguilla (L.), populations in the River Severn, England, and the River Dee, Wales. Aquaculture and Fisheries Management 19: 365-376.

Baisez, A. \& Laffaille, P. 2005. Un outil d'aide à la gestion de l'anguille: le tableau de bord anguille du bassin Loire. Bulletin Français de la Pêche et de la Pisciculture 378-379: 115-130.

Baras, E., Philippart, J.-C. \& Salmon, B., eds. 1996. Estimation of migrant yellow eel stock in large rivers through the survey of fish passes: a preliminary investigation in the River Meuse (Belgium). In: Stock Assessment in Inland Fisheries. Oxford, UK: Fishing News Books, pp. 82-92.

Briand, C., Fatin, D., Fontenelle, G. \& Feunteun, E. 2005. Effect of re-opening of a migratory pathway for eel (Anguilla anguilla, L.) at a watershed scale. Bulletin Français de la Pêche et de la Pisciculture 378-379: 67-86.

Chisnall, B.L. 1989. Age, growth, and condition of freshwater eels (Anguilla sp.) in backwaters of the lower Waikato River, New Zealand. New Zealand Journal of Marine and Freshwater Research 23: 459-465.

Commission of the European Community. 2007. Council Regulation (EC) No. 1100/2007 of 18 September 2007 Establishing Measures for the Recovery of the Stock of European Eel [WWW document]. URL http://eur-lex. europa.eu/LexUriServ/LexUriServ.do?uri=OJ:L:2007:248: 0017:0023:EN:PDF.

Cone, R.S. 1989. The need to reconsider the use of condition indexes in fishery science. Transactions of the American Fisheries Society 118: 510-514.

Copp, G. 1989. The habitat diversity and reproductive function of floodplain ecosystems. Environmental Biology of Fishes 26: 1-27.

Costa, J.L., Domingos, I., Assis, C.A., Almeida, P.R., Moreira, F., Feunteun, E. \& Costa, M.J. 2008. Comparative ecology of the European eel, Anguilla anguilla (L., 1758), in a large Iberian river. Environmental Biology of Fishes 81: 421434.

Daverat, F. \& Tomas, J. 2006. Tactics and demographic attributes in the European eel Anguilla anguilla in the Gironde watershed, SW France. Marine Ecology Progress Series 307: 247-257. 
Daverat, F., Limburg, K.E., Thibault, I., Shiao, J.C., Dodson, J.J., Caron, F.O., Tzeng, W.N., Iizuka, Y. \& Wickstrom, H. 2006. Phenotypic plasticity of habitat use by three temperate eel species, Anguilla anguilla, A. japonica and A. rostrata. Marine Ecology Progress Series 308: 231-241.

Davey, A.J.H. \& Jellyman, D.J. 2005. Sex determination in freshwater eels and management options for manipulation of sex. Reviews in Fish Biology and Fisheries 15: $37-$ 52.

Domingos, I., Costa, J.L. \& Costa, M.J. 2006. Factors determining length distribution and abundance of the European eel, Anguilla anguilla, in the River Mondego (Portugal). Freshwater Biology 51: 2265-2281.

Edeline, E. 2007. Adaptive phenotypic plasticity of eel diadromy. Marine Ecology Progress Series 341: 229232.

Edeline, E., Lambert, P., Rigaud, C. \& Elie, P. 2006. Effects of body condition and water temperature on Anguilla anguilla glass eel migratory behavior. Journal of Experimental Marine Biology and Ecology 331: 217-225.

EELREP. 2005. Final Report: Estimation of the Reproduction Capacity of European Eel. EU-project EELREP (Q5RS-200101836). [WWW document]. URL http://www.fishbiology.net/ EELREP_final_report.pdf.

Feunteun, E. 1994. Le peuplement piscicole du marais littoral endigué de Bourgneuf-Machecoul (France Loire-Atlantique). Approche méthodologique pour une analyse quantitative de la distribution spatiale du peuplement piscicole et de la dynamique de certaines de ses populations. Ph.D. thesis. Université Rennes I. 240+ annexes pp.

Feunteun, E. 2002. Management and restoration of European eel population (Anguilla anguilla): an impossible bargain. Ecological Engineering 18: 575-591.

Feunteun, E., Acou, A., Guillouet, J., Laffaille, P. \& Legault, A. 1998. Spatial distribution of an eel population (Anguilla anguilla L.) in a small coastal catchment of northern Brittany (France). Consequences of hydraulic works. Bulletin Francais de la Pêche et de la Pisciculture 349: 129-139.

Feunteun, E., Laffaille, P., Robinet, T., Briand, C., Baisez, A., Ollivier, J.-M. \& Acou, A., eds. 2003. A review of upstream migration and movements in inland waters by anguillid eels: toward a general theory. In: Eel Biology. Tokyo: SpringerVerlag, pp. 191-213.

Garcia, F.-X. \& Laville, H. 2000. Spatio-temporal distribution of the chironomid population in the lower part of a large river: the Middle Loire (France). Verhandlungen der Internationale Vereinigung Limnologie 27: 2524.

Granado-Lorencio, C., Araujo Lima, C.R.M. \& Lobon-Cervia, J. 2005. Abundance-distribution relationships in fish assembly of the Amazonas floodplain lakes. Ecography 28: 515-520.

Ibbotson, I., Smith, J., Scarlett, P. \& Aprahamian, M.W. 2002. Colonisation of freshwater habitats by the European eel Anguilla anguilla. Freshwater Biology 47: 1696-1706.

Ihaka, R. \& Gentleman, R. 1996. R: a language for data analysis and graphics. Journal of Computational and Graphical Statistics 5: 299-314.

Junk, W.J., Bayley, P.B. \& Sparks, R.E. 1989. The flood pulse concept in river-floodplain systems. Canadian Special Publication of Fisheries and Aquatic Sciences 106: 110-127.
Krueger, W.H. \& Oliveira, K. 1999. Evidence for environmental sex determination in the American eel, Anguilla rostrata. Environmental Biology of Fishes 55: 381-389.

Laffaille, P., Feunteun, E., Baisez, A., Robinet, T., Acou, A., Legault, A. \& Lek, S. 2003. Spatial organisation of European eel (Anguilla anguilla L.) in a small catchment. Ecology of Freshwater Fish 12: 254-264.

Laffaille, P., Baisez, A., Rigaud, C. \& Feunteun, E. 2004. Habitat preferences of different European eel size classes in a reclaimed marsh: a contribution to species and ecosystem conservation. Wetlands 24: 642-651.

Laffaille, P., Acou, A. \& Guillouet, J. 2005a. The yellow European eel (Anguilla anguilla L.) may adopt a sedentary lifestyle in inland freshwaters. Ecology of Freshwater Fish 14: 191-196.

Laffaille, P., Briand, C., Fatin, D., Lafage, D. \& Lasne, E. 2005b. Point sampling the abundance of European eel (Anguilla anguilla) in freshwater areas. Archiv für Hydrobiologie 162: 91-98.

Lasne, E. \& Laffaille, P. 2008. Analysis of distribution patterns of yellow European eels in the Loire catchment using logistic models based on presence-absence of different size-classes. Ecology of Freshwater Fish 17: 30-37.

Lasne, E., Lek, S. \& Laffaille, P. 2007. Patterns in fish assemblages in the Loire floodplain: the role of hydrological connectivity and implications for conservation. Biological Conservation 139: 258-268.

Melià, P., Bevacqua, D., Crivelli, A.J., Panfili, J., De Leo, G.A. \& Gatto, M. 2006. Sex differentiation of the European eel in brackish and freshwater environments: a comparative analysis. Journal of Fish Biology 69: 1228-1235.

Moriarty, C. 1986. Riverine migration of young eels Anguilla anguilla (L.). Fisheries Research 4: 43-58.

Moriarty, C. \& Dekker, W. 1997. Management of the European eel. Fisheries Bulletin (Dublin) 15: 1-110.

Morrison, W.E. \& Secor, D.H. 2003. Demographic attributes of yellow-phase American eels (Anguilla rostrata) in the Hudson River estuary. Canadian Journal of Fisheries and Aquatic Sciences 60: 1487-1501.

Mounaix, B. \& Fontenelle, G. 1994. Anguilles estuariennes et fluviales: apports de l'otolithométrie. Bulletin Français de la Pêche et de la Pisciculture 335: 67-80.

Naismith, I.A. \& Knights, B. 1988. Migrations of elvers and juvenile European eels, Anguilla anguilla L., in the River Thames. Journal of Fish Biology 33: 161-175.

Nelva, A., Persat, H. \& Chessel, D. 1979. Une nouvelle méthode d'étude des peuplements ichthyologiques dans les grands cours d'eau par échantillonnage ponctuel d'abondance. Comptes Rendus de l'Académie des Sciences de Paris, Série D 289: 679-791.

Packard, G.C. \& Boardman, T.J. 1999. The use of percentages and size-specific indices to normalize physiological data for variation in body size: wasted time, wasted effort? Comparative Biochemistry and Physiology a-Molecular and Integrative Physiology 122: 37-44.

Reckendorfer, W., Baranyi, C., Funk, A. \& Schiemer, F. 2006. Floodplain restoration by reinforcing hydrological connectivity: expected effects on aquatic mollusc communities. Journal of Applied Ecology 43: 474-484.

Ribeiro, F., Crain, P.K. \& Moyle, P.B. 2004. Variation in condition factor and growth in young-of-year fishes in 


\section{Lasne et al.}

floodplain and riverine habitats of the Cosumnes River, California. Hydrobiologia 527: 77-84.

Robinet, T. \& Feunteun, E. 2002. Sublethal effects of exposure to chemical compounds: a cause for the decline in Atlantic eels? Ecotoxicology 11: 265-277.

Thomaz, S.M., Bini, L.M. \& Bozelli, R.L. 2007. Floods increase similarity among aquatic habitats in river-floodplain system. Hydrobiologia 579: 1-13.

Tockner, K. \& Stanford, J.A. 2002. Riverine floodplains: present state and future trends. Environmental Conservation 29: $308-330$.
Tockner, K., Schiemer, F., Baumgartner, C., Kum, G., Weigand, E., Zweimüller, I. \& Ward, J.V. 1999. The Danube restoration project: species diversity patterns across connectivity gradients in the floodplain system. Regulated Rivers: Research and Management 15: 245-258.

Vila-Gispert, A., Zamora, L. \& Moreno-Amich, R. 2000. Use of the condition of Mediterranean barbel (Barbus meridionalis) to assess habitat quality in stream ecosystems. Archiv für Hydrobiologie 148: 135-145.

Ward, J.V. \& Tockner, K. 2001. Biodiversity: towards a unifying theme for river ecology. Freshwater Biology 46: 807-819. 